\title{
POLITYCZNA IDEOLOGIZACJA RELIGII ZAGROŻENIEM BEZPIECZEŃSTWA PAŃSTW W OBSZARZE BASENU MORZA ŚRÓDZIEMNEGO
}

\author{
Andrzej Sołtys \\ Politechnika Rzeszowska, \\ Wydział Zarządzania, Zakład Nauk Humanistycznych \\ e-mail: asoltys@prz.edu.pl
}

\begin{abstract}
Streszczenie. Celem artykułu jest zrekonstruowanie mechanizmów ideologizowania religii w nowożytnym i współczesnym pojęciu polityki oraz ukazanie zagrożeń dla wewnętrznego bezpieczeństwa państw, jakie ten proces pociąga. Zagrożenie bezpieczeństwa wynikające z procesu ideologizowania religii ilustruje się w artykule współczesnym islamizmem, który inspiruje działania organizacji terrorystycznych w niektórych państwach basenu Morza Śródziemnego. W warstwie teoretycznej proces ideologizowania religii przejawia się tym, iż twierdzeniom religijnym o znaczeniu transcendentalnym nadaje się charakter immanentny, natomiast $\mathrm{w}$ warstwie praktycznej tym, że cele mające znaczenie dla grupy społecznej przedkłada się nad cele wynikające $\mathrm{z}$ istoty religii i mające znaczenie dla jednostki. W artykule ukazuje się nowożytne źródła ideologizowania religii oraz nowożytne i współczesne mechanizmy przekształcania religii w ideologię władzy. Uwyraźnia się przyczynowy związek między zideologizowaną postacią religii i zagrożeniem wewnętrznego bezpieczeństwa państw.
\end{abstract}

Słowa kluczowe: bezpieczeństwo, ideologia, ideologizacja religii, polityka, terroryzm

\section{WSTĘP}

W klasycznym modelu kultury religia jest ukazywana jako ogniskowa wszystkich dziedzin kultury. ${ }^{1}$ Znaczy to, że religia scala poszczególne dziedziny kultury, inspiruje zorientowaną na religię aktywność w tych dziedzinach. Jednakże własną rolą religii jest wskazać człowiekowi sposób przeżywania egzystencji i dostarczyć odpowiednich środków umożliwiających jego zbawienie. Religia

1 Zob. M. A. Krąpiec, U podstaw rozumienia kultury, RW KUL, Lublin 1991, s. 217-249; Z. J. Zdybicka, Religia $w$ kulturze. Studium z filozofii religii, Polskie Towarzystwo Tomasza z Akwinu, Lublin 2010. 
spełnia to zadanie wówczas, gdy nie jest poddawana ideologizacji polegającej na uznawaniu za właściwe innych jej zadań. Najwyrazistszą postacią oderwania religii od istotnych jej zadań jest wprzęgnięcie religii w politykę i posługiwanie się nią w realizowaniu politycznych celów. Można mówić wówczas o politycznej ideologizacji religii, która nieuchronnie pociąga zagrożenie naruszenia wewnętrznego bezpieczeństwa państw w obszarze kulturowym oraz bezpieczeństwa kulturowego. ${ }^{2} \mathrm{~W}$ niniejszym studium wskażemy na polityczną ideologizację religii poniekąd wpisaną w nowożytny i współczesny model uprawiania polityki. Chodzi o zrekonstruowanie politycznych mechanizmów przekształcania religii w ideologię władzy. We wskazanym procesie jednakowo mogą brać udział zarówno politycy, jak też ich oponenci. W artykule poszukujemy odpowiedzi na pytanie: Kiedy religia zagraża bezpieczeństwu wewnętrznemu państwa? Wskażemy na jaskrawe współczesne przejawy ideologizowania religii i powodowane przez ten proces groźne skutki dla bezpieczeństwa wewnętrznego państw. Przykładów tych dostarczają organizacje terrorystyczne działające w obszarze BMŚ. Chodzi głównie o grupy islamskie, które ideologizują religię do urzeczywistniania własnych, najczęściej politycznych celów.

\section{IDEOLOGIA A RELIGIA}

Istnieje wiele definicji i znaczeń zarówno terminu ideologia jak i religia. O ideologii i religii mówi się nierzadko w taki sposób, jak gdyby należały one do tej samej kategorii logicznej. ${ }^{3}$ I to specjalnie nie dziwi, jako że zarówno w ideologii, jak i w religii występuje porządek głoszonych prawd oraz porządek określający sposób postępowania. W zderzeniu ideologii z religią ważne są nie tyle podobieństwa, ile raczej zachodzące między nimi różnice.

Ideologię można pojmować szeroko bądź wąsko. Z ideologią szeroko pojętą łączy się całokształt poglądów na świat i ludzkie życie przyjmowanych przez jakąś grupę społeczną. Służą one określonej grupie społecznej do utrzymania bądź przekształcania już istniejącego porządku społecznego. Pojęcie ideologii współtworzy więc historycznie, kulturowo i społecznie uwarunkowana doktryna, na którą składają się przekonania i wartościowania dające całościowy obraz rzeczywistości. Integralnym elementem ideologii są postulaty dotyczące celów i metod działania grupy społecznej. Przy wąskim rozumieniu ideologia obejmuje doktrynę zawierającą poglądy dotyczące aktualnej sytuacji politycznej, społecznej i ekonomicznej danej społeczności. Stosownie do tych poglądów wykształca się

2 Szeroko na temat bezpieczeństwa kulturowego zob. Worlds on the move: globalization migration and cultural security, red. J. Friedman, Jonathan, S. Randeria, London, New York 2004; The Routledge handbook of religion and security, red. P. Otis, Ch. Seiple, D. Hoover, LondonNew York 2013.

3 Por. Ideologia, [w:] Britanica - edycja polska, t. 17, red. W. Wolarski, Wydawnictwo Kurpisz, Poznań 2000, s. 45. 
program polityczny dostarczający wskazań, jak realizować w czasie i przestrzeni interes identyfikującej się z ideologią grupy społecznej. Ideologie różnią się między sobą ze względu na dominującą treść w ich doktrynach. Konsekwentnie na ich podstawie wykształca się projekt praktycznego działania. Ze względu na powyższe istotne jest to, aby skoncentrować się na postrzeganiu fenomenu religii jako kategorii logicznej odmiennej od ideologii.

Religia jest fenomenem powszechnym. Zdaniem Ericha Fromma ,nie byto takiej kultury w przeszłości i jak się zdaje nie może być takiej kultury w przyszłości, która by nie miała religii”. ${ }^{4}$ Mimo powszechnego charakteru religia nie jest łatwym fenomenem do opisywania, a tym bardziej do definiowania. Rozbieżności pojawiają się w kwestii odpowiedzi na pytania: Czym religia jest? Jakie są jej źródła? Jaką pełni funkcję w życiu jednostkowym i społecznym? $\mathrm{Z}$ badanego przez nas punktu widzenia ważne jest ustalenie: Czym religia jest? Co jest odpowiednim dla człowieka przedmiotem religii? Dlaczego religia istnieje? Odpowiedzi na te pytania są ze sobą ściśle zespolone. Polski filozof religii Z. J. Zdybicka, biorąc pod uwagę istotne momenty przeżycia religijnego, proponuje, aby rozumieć religię jako układ relacji człowieka do jakiejś istoty najwyższej lub najwyższej wartości, uświadomiony i wyrażający się w specjalnym zachowaniu się człowieka: uznaniu zależności, pragnieniu oddania czci, dążeniu do jak najściślejszego związania się z nią. ${ }^{5}$

Znalezienie odpowiedniego dla człowieka przedmiotu religii zakłada wiedzę z zakresu antropologii filozoficznej i metafizyki. Trudno się spodziewać, aby badacz religii zakładający naturalizm metodologiczny doszedł do ustalenia właściwego człowiekowi przedmiotu religii. Ten bowiem w kwestii przedmiotu religijnego nie będzie się mógł w ogóle wypowiadać. A zatem, formułowane przez pozytywistów, scjentystów twierdzenia, iż Bóg nie istnieje, bądź Bóg jest wytworem człowieka, wykraczają poza ich kompetencje naukowe. W naturalistyczny paradygmat nauki zajmującej się religią wpisują się tylko te dyscypliny, które badają naturalne przejawy fenomenu religii. ${ }^{6}$ Nie mogą się natomiast wypowiadać o przedmiocie religii, który wymyka się przecież obserwacyjnym metodom badawczym. W konsekwencji te dyscypliny nauki, które mieszczą się w paradygmacie metodologicznego naturalizmu, są bez znaczenia dla wiedzy o odpowiednim dla człowieka przedmiocie religii.

Badanie fenomenu religii nie ma większego znaczenia dla poszczególnych ludzi. Ale każdy z ludzi dąży do zdobycia wiedzy całościowej dotyczącej samego siebie oraz świata przyrody. Zanurzony we własnej egzystencji człowiek

${ }^{4}$ E. Fromm, Szkice z psychologii religii, thum. J. Prokopiuk, „Książka i Wiedza”, Warszawa 1966, s. 134.

5 Por. Z. J. Zdybicka, Religia i religioznawstwo, RW KUL, Lublin 1988, s. 23.

6 Por. J. Waardenburg, „Religionswissenschaft” New Style. Some Thought and Afterthoughts, „Annual Review of the Social Science of Religion” 2 (1978), s. 190. 
$(\text { In-der-Welt-seins })^{7}$ poszukuje innych odpowiedzi na powyższe kwestie, aniżeli te, jakich mogą mu dostarczyć nauki pozytywne, a nawet filozofia. Dąży do zdobycia nie tylko wiedzy dotyczącej różnych dziedzin życia, ale chce poznać całą rzeczywistość. ${ }^{8}$ Chce znać to, kim jest, jakie jest jego miejsce w rzeczywistości, jaki w ogóle sens ma jego życie i to, jak się wydaje, jest wiedza niezbędna do tego, aby człowiek po ludzku żył. Skoro do takiej wiedzy człowiek nie dochodzi ani na gruncie nauk pozytywnych, a nawet na gruncie filozofii, to mając potrzebę wspomnianej wiedzy naturalnie otwiera się na religię. Religia odsłania przed nim te wymiary jego egzystencji, których nie mogą badać ani nauki szczegółowe, ani nawet filozofia. ${ }^{9}$ Ustawiając siebie w perspektywie religijnej, człowiek ma dostęp do innego typu poznania Boga i swojego stosunku do Niego aniżeli jest mu w stanie dostarczyć teodycea czy filozofia religii. W poznaniu przez wiarę religijną dochodzi do wiedzy o Bogu i pełnej wiedzy o sobie samym.

Wiedza religijna ma znaczenie praktyczne. Składają się na nią przekonania o sensie własnej egzystencji, i to one wyznaczają człowiekowi kierunek pracy nad sobą. Człowiekowi towarzyszy jednocześnie świadomość, że zadania tego nie może zrealizować osobiście. Stąd w religii odnajduje duchową pomoc umożliwiającą jego spełnienie. W religii człowiek, wchodząc w żywą relację z Bogiem, przekracza swoimi pragnieniami i zdolnościami przyrodę i społeczeństwo. Poprzez dialog i jednoczenie się z Bogiem uzyskuje nową postać godności moralnej. Realizacja celu soteriologicznego jawi się jako główne i pierwsze zadanie, jakie ma spełnić religia w zindywidualizowanej egzystencji ludzkiej. To, co istotne $\mathrm{w}$ fenomenie religii, odsłoni się $\mathrm{w}$ zderzeniu religii z ideologią.

Zarówno religię jak i ideologię definiuje system twierdzeń doktrynalnych oraz postulowany sposób działania. Treści twierdzeń religijnych nie mogą badać ani nauki przyrodnicze, ani filozofia. Twierdzenia religijne dotyczą ludzkiej egzystencji i Boga oraz związku ludzkiej egzystencji z Bogiem. Inaczej ma się rzecz z doktryną ideologiczną, której twierdzenia w odróżnieniu od twierdzeń religijnych mają charakter immanentny, dotyczą bowiem sytuacji politycznej, społecznej, ekonomicznej i kulturowej. Pierwsza istotna różnica, jaka rysuje się między religią i ideologią, dotyczy więc treści religijnych twierdzeń oraz treści doktryny ideologicznej.

Zarówno religia, jak i ideologia zawierają wskazania praktyczne. Na ich podstawie planuje się strategie działań, poprzez które osiąga się cele wskazane przez doktrynę religijną i ideologiczną. Ideologia z racji immanentnej w stosunku do świata treści doktrynalnej dysponuje najczęściej wiedzą socjologiczną, która jest wykorzystywana do realizowania interesów grupy społecznej. Religia natomiast przez treść swych twierdzeń wykracza poza świat, w którym żyjemy, bazuje na wiedzy

7 Por. J. Mizera, Ontologia fundamentalna Martina Heideggera, [w:] Filozofia wspótczesna, red. J. Tischner, Kraków 1989, s. 89.

8 Por. Z. J. Zdybicka, Religia i religioznawstwo..., s. 247.

9 Ibidem, s. 253. 
pozaracjonalnej i na tej podstawie dostarcza wskazań o charakterze praktycznym, to znaczy określa, jak żyć, jak postępować, aby dostąpić zbawienia. ${ }^{10}$ Praktyczne postulaty religii mają więc dla każdego człowieka osobiste znaczenie. Inaczej doktryna ideologiczna, która ma pierwszorzędne znaczenie dla grupy społecznej. Nie odbiera ona wszakże jednostce możliwości realizowania własnych interesów pod warunkiem, że jednostka będzie to robić w ramach celów grupowych. W ideologii interesy grupowe uprzedzają interesy jednostek. Religia w przeciwieństwie do ideologii nie zawiera programów działań grupowych. I właśnie wtedy dochodzi do ideologizacji religii, gdy religię wykorzystuje się do urzeczywistniania celów grupowych. Przykładu takiej ideologizacji dostarczają organizacje terrorystyczne wpisujące religię w program wspomnianych działań grupowych. ${ }^{11}$

Doktryna religijna w przeciwieństwie do doktryny ideologicznej ma pierwszorzędne znaczenie dla jednostki. Wyjaśnia ważne dla człowieka kwestie egzystencjalne, a mianowicie to, jak realizować osobiste zbawienie. W religii człowiek staje przed Bogiem nie jako ten, który zgłasza przed Nim żądania czy życzenia, lecz jako racjonalny i wolny podmiot zafascynowany Jego obecnością. Doktryna religijna nie dopuszcza myślenia życzeniowego, a posługiwanie się czynnościami o charakterze religijnym w celu wymuszenia na bóstwie spełnienia oczekiwań deformuje samą naturę religii. ${ }^{12}$ Bywa, że również ideologia propaguje interesy grupowe jako jedynie słuszne i prowadzące do szczęścia, raju etc., ale wówczas staje się ona namiastką religii. ${ }^{13}$ Jednakże częściej to religia bywa wykorzystywana do realizacji interesów jakiejś grupy społecznej. Ideologizowanie religii polega więc na jej wykorzystywaniu do obrony bądź legitymizowania tych interesów. Religia jest wówczas wprzęgnięta $\mathrm{w}$ realizację celów niezgodnych $\mathrm{z}$ jej istotną rolą. Wyznacza się jej rolę, jaką ma do spełnienia ideologia.

Współczesny niemiecki filozof religii Bernhard Welte wyróżnił cztery formy ideologizowania religii. ${ }^{14}$ Jest to ideologizacja poprzez społeczną instrumentalizację, ideologizacja poprzez absolutyzowanie człowieka, ideologizacja estetyczna oraz ideologizacja ze względu na prestiż. Spośród wymienionych form jedną z najbardziej jaskrawych postaci ideologizowania religii jest pierwsza jej postać. Polega ona na posługiwaniu się religią w celu zdobycia władzy nad ludźmi i jej utrzymania. $Z$ religii czyni się instrument w rękach polityków bądź ich

${ }^{10}$ Por. A Sołtys, Logiczna charakterystyka języka religijnego, Roczniki Teologiczne, Teologia Fundamentalna i Religiologia 55 (2008), z. 9, s. 99.

${ }^{11} \mathrm{~W}$ basenie Morza Śródziemnego przykładem takich organizacji terrorystycznych jest utworzony w 1982 r. w Libanie Hezbollah, natomiast w Palestynie w 1987 r. Hamas. Statut Hamasu z 1988 r. stwierdza wprost, że głównym i pilnym zadaniem organizacji jest stworzenie państwa islamskiego na całym terytorium Palestyny włącznie z Jerozolimą Wschodnią. Zob. B. Hołyst, Terroryzm, wyd. 2, t. 1, Lexis Nexis, Warszawa 2011, s. 674-683.

${ }_{12}$ Por. J. Herbut, Ideologia a doktryna religijna, [w:] Oblicza dialogu, red A. B. Stępień i T. Szubka, RW KUL, Lublin 1992, s. 24-25.

${ }^{13}$ Por. ibidem, s. 24.

${ }^{14}$ Zob. B. Welte, Ideologie und Religion, [w:] Christlicher Glaube in moderner Gesellschaft, t. 21, Freiburg 1980, s. 99-103. 
oponentów, a nierzadko fasadę zasłaniającą mało szlachetne cele, do których politycy bądź ich oponenci dążą. Przykładu tego typu dążeń i działań dostarczają partie polityczne, które swoje programy legitymizują doktryną religijną. W tych okolicznościach trudno nie przyznać Marksowi racji, który w religii dostrzegał już tylko narzędzie do sprawowania władzy nad proletariatem..${ }^{15}$ Religia, w jego przekonaniu, była opium dla ludu, czyli środkiem usypiającym czujność rządzonych, środkiem powodującym błogostan. Jeśli więc Marks nie doświadczył religii w czystej postaci, a spotykał się na co dzień z jej postacią zideologizowaną, to nie może dziwić jego wrogi stosunek do religii. ${ }^{16}$ Negatywna ocena religii w pismach Marksa wynikała z uznania jej za ideologię, natomiast każda ideologia była, jego zdaniem, przejawem fałszywej świadomości. ${ }^{17}$

Zarysowany typ ideologizacji religii z wykorzystaniem przemocy i gwałtu stosuje współczesny islamizm. Stwarza tym samym zagrożenie bezpieczeństwa wewnętrznego państw. Pojęciem islamizmu oznacza się uprawnione formy politycznego ekstremizmu motywowane religią islamu. ${ }^{18}$ Islamizm więc funduje ideologiczno-religijne umotywowanie działań organizacji terrorystycznych. W czasie ostatnich 20 lat w państwach BMŚ najpoważniejsze w skutkach ataki terrorystyczne były umotywowane właśnie religią islamu. ${ }^{19} \mathrm{~W}$ kwietniu $1996 \mathrm{r}$. przed hotelem w Kairze egipscy bojownicy islamscy obrzucili granatami ręcznymi zachodnich turystów, co spowodowało śmierć 18 osób. W roku 1997 w egipskim Luksorze terroryści należący do al-Gamat al-Islamija (Grupy Islamskiej) dokonali masakry w tamtejszej świątyni królowej Hatszepsut. Zginęło wówczas 58 zagranicznych turystów i czworo Egipcjan. W Algierii Zbrojna Grupa Islamska, przeprowadzając liczne zamachy terrorystyczne, doprowadziła do śmierci 2 tysięcy osób tylko w trzech kwartałach $2001 \mathrm{r}^{20}$

Zamachy terrorystyczne motywowane religią islamu nie oszczędziły także krajów europejskich z BMŚ. W roku 1994 wspomniana wyżej Algierska Zbrojna Grupa Islamska dokonała porwania pasażerskiego odrzutowca Air France. Założono widowiskowe wysadzenie w powietrze tegoż samolotu z 283 pasażerami i terrorystami dokładnie nad Paryżem w taki sposób, aby płonący wrak samolotu spadł na gęsto zaludnione miasto. Na szczęście porwanie się nie powiodło. Innym był zamach terrorystyczny 11 marca $2004 \mathrm{r}$. w pociągach dowożących ludzi $\mathrm{z}$ okolic podmiejskich do pracy w Madrycie. ${ }^{21}$ Zamach przeprowadziła Islamska Marokańska Grupa Zbrojna, używając trzynastu ładunków wybuchowych, z których dziewięć eksplodowało. W efekcie symultanicznych ataków bombo-

\footnotetext{
${ }^{15}$ Por. B. Welte, Filozofia religii, thum. G. Sowiński, „Znak”, Kraków 1996, s. 246-247.

${ }^{16}$ Por. Oblicza dialogu..., s. 190.

${ }^{17}$ Zob. K. Marks, F. Engels, Ideologia niemiecka, [w:] Dzieła, t. 3, Warszawa 1962; por. Ideologia, [w:] Britanica - edycja polska,..., s. 46.

${ }^{18}$ Por. B. Hołyst, op. cit., s. 498.

${ }^{19}$ Por. ibidem, s. 473-474.

${ }^{20}$ Por. ibidem, s. 706.

${ }^{21}$ Zob. ibidem, s. 897-899.
} 
wych na cztery pociągi w ciągu czterech minut zginęło 191 osób, a ponad dwa tysiące zostało rannych. W kilka dni po zamachu 14 marca odnaleziono kasetę wideo, na której przywódca Al-Kaidy w Europie przyznaje się do zamachów i wyjaśnia, że zostały one dokonane w odwecie za udział wojsk hiszpańskich w okupacji Iraku. Konsekwencją zamachów był gniew obywateli Hiszpanii na rządzącą w tym kraju partię ludową, która wysłała wojska hiszpańskie do Iraku. W zaplanowanych i przeprowadzonych 14 marca wyborach wygrała wówczas partia socjalistyczna, której przywódca José Luis Rodriguez Zapatero, premier elekt, potępił wojnę w Iraku i zapowiedział wycofanie wojsk hiszpańskich z tego kraju. Obietnicę w krótkim czasie spełnił. Motywowani religią islamu terroryści wpłynęli po raz pierwszy na wynik wyborów w państwie europejskim oraz na politykę jego rządu. Są to tylko niektóre, najpoważniejsze w skutkach zamachy terrorystyczne powodowane ideologizacją religii. Jednakże ideologizowanie religii niesie jeszcze większe niebezpieczeństwo aniżeli jednostkowe i punktualne działania terrorystyczne. Tym niebezpieczeństwem są wojny religijne. Johnson odnotowuje, że współcześnie w wojny religijne, głównie na Bliskim Wschodzie, zaangażowanych jest więcej ludzi aniżeli w całej drugiej wojnie światowej. ${ }^{22}$

Bliską wyżej zarysowanej postaci zideologizowania religii jest ideologizacja religii przez absolutyzację człowieka. ${ }^{23}$ Teoretyczne podstawy dla tej formy ideologizowania religii wypracował Ludwik Feuerbach. ${ }^{24}$ Utrzymywał, że obiektywnie nie istnieje transcendentny przedmiot religii, a religię i boga stworzył człowiek. Transcendentne „ty” to obiektywizacja cech gatunkowych człowieka. Jednostka, nie mogąc sprostać niektórym wyzwaniom, tworzy ideę boga, który jest w mocy zmierzyć się z niemożliwymi do spełnienia przez jednostkę zadaniami. Jednostka nie ma świadomości, że tym bogiem jest gatunek ludzki, gdyż dopiero człowiek gatunkowo wzięty może sprostać tym szczególnego typu wyzwaniom. Bóg zatem to zhipostazowana idea ludzkiego gatunku (homo homini deus est).$^{25}$ Feuerbach postuluje więc, aby naszą religią była odtąd polityka. ${ }^{26}$ Polityka bowiem oddaje cześć gatunkowi ludzkiemu jako swojemu bogu.

\section{IDEOLOGIZACJA RELIGII W NOWOŻYTNYM POJĘCIU POLITYKI}

Obecność religii w przestrzeni publicznej była i jest przedmiotem sporu. Jedne siły polityczne, które wspierają swój program polityczny doktryną religijną, nie wyobrażają sobie zepchnięcia religii w sferę życia prywatnego. Inne, przyjmując

${ }^{22}$ Cyt. za B. Hołyst, Terroryzm, wyd. 2, t. 2, Lexis Nexis, Warszawa 2011, s. 1654, przyp. 13.

${ }^{23}$ Zob. Z. J. Zdybicka, Alienacja zasadnicza: czlowiek bogiem, [w:] Filozofia wzloty i upad$k i$, RW KUL, Lublin 1998, s. 23-37.

${ }^{24}$ Zob. L. Feuerbach, Wybór pism, Zasady filozofii przyszłości, przeł. K. Krzemieniowa, M. Skwieciński, t. 2, Państwowe Wydawnictwo Naukowe, Warszawa 1988, s. 166-183.

${ }^{25}$ Por. ibidem, s. 168.

${ }^{26}$ Por. F. Copleston, Historia filozofii, t. 7, „Pax”, Warszawa 1995, s. 302. 
program obcy religii, nie widzą dla niej miejsca w przestrzeni publicznej i konsekwentnie dążą do wyeliminowania z niej religii. Ważną kwestią jest także to, jaką przestrzeń dla swojej aktywności religijnej wyznaczają sami wyznawcy religii. W przypadku religii chrześcijańskiej proces ideologizowania religii zapoczątkowali sami jej wyznawcy. W społeczności chrześcijańskiej we Florencji doszło do niebezpiecznego zbliżenia religii do ideologii, a z czasem do ich utożsamienia. ${ }^{27}$ Florencja była świadkiem narodzin nowoczesności, i to w niej wykreowano ideologicznego chrześcijanina. ${ }^{28}$ Stało się to za sprawą wpływowego dominikanina Girolama Savonaroli. ${ }^{29}$ Savonarola skierował religię na niebezpieczne tory autoideologizacji. Postrzegał on wspólnotę chrześcijańską jako model, który ludzie powinni wprowadzać w życie niezależnie od tego, do czego dąży państwo. Savonarola w urzeczywistnianiu własnego modelu wspólnoty chrześcijańskiej odwoływał się do pospólstwa. Podporządkował sobie w ten sposób aparat państwa. Następnie, kiedy państwo było mu już wystarczająco uległe, wykorzystał moc państwa do kontroli gospodarki oraz prywatnego życia obywateli. W jego działalności doszło do niebezpiecznego zbliżenia religii chrześcijańskiej i ideologii. Nadał on chrześcijaństwu formę ideologiczną. Odtąd kontynuatorzy takiego kształtu chrześcijaństwa systematycznie wprowadzali do religii przekonania określające strukturę społeczeństwa i praktyczny program społecznego działania wraz z immanentnymi celami. Rozmycie istotnych funkcji religii wykorzystał następnie Machiavelli i poddał religię procesowi zewnętrznej politycznej ideologizacji. Proces ten był wpisany w przyjmowaną przezeń koncepcję polityki.

Machiavelli uważał, że to skuteczność przydaje polityce wartości. Z tego względu polityka jest poza dobrem i złem, podobnie też i państwo, które politykę legitymizuje. ${ }^{30}$ Machiavelli uczynił z polityki sztukę rządzenia polegającą na dochodzeniu do władzy i jej utrzymaniu. W swoim traktacie Książe, poświęconym polityce, opisał wzór prawdziwego polityka i władcy. Polityk, dochodząc do władzy i sprawując ją, okaże się wtedy skuteczny, gdy nie będzie się liczył z wartościami moralnymi. Machiavelli nie twierdził przy tym, że sztuka sprawowania władzy przeciwstawia się porządkowi moralnemu. Utrzymywał tylko, że polityka jest od moralności niezależna. Polityka nie jest ani moralna, ani amoralna. Stąd Książę w traktacie Machiavellego, będący uosobieniem prawdziwego władcy, w sztuce rządzenia powinien respektować zasady moralne tylko wtedy, gdy ich respektowanie uczyni skutecznym rządzenie, $w$ przeciwnym razie nie tylko nie ma obowiązku, ale nawet nie powinien się liczyć z tymi zasadami. Prawdziwy władca nie może się cofać ani przed okrucieństwem, ani przed lagodnością, lecz musi umieć po nie sięgnąć, gdy za ich pomocą będzie mógł uczynić rządzenie skuteczniejszym.

${ }^{27}$ Por. B. Welte, Filozofia religii,..., s. 247-248.

${ }^{28}$ Por. Ideologia, [w:] Britanica - edycja polska,..., s. 45.

${ }^{29}$ Zob. N. Hugedé, Savonarola i Florentczycy, „Pax”, Warszawa 1988.

${ }^{30}$ Por. N. Machiavelli, Książe, thum. Cz. Nanke, Antyk, Kęty 2004, Przedmowa thumacza, s. 13. 
Machiavelli nie kwestionował znaczenia kategorii moralnych ani w życiu jednostek, ani w życiu społecznym. Relatywizował natomiast ich rolę w aktywności politycznej. Nie podważał także związku zachodzącego pomiędzy kategoriami moralnymi a religią chrześcijańską. Religię podobnie jak i moralność wprzęgał w politykę i uzależniał od niej praktykowanie religii. Dotąd religia dominowała nad polityką. Zdaniem Machiavellego wspomniana dominacja religii nad polityką uczyniła ludzkość niezdolną do wolności i politycznej aktywności. Tymczasem Książę - uosobienie dobrego władcy umiał wprzęgnąć moralną dobroć oraz religię w proces dochodzenia do władzy i jej sprawowania ${ }^{31}$. Dlatego jednym razem, gdy tego wymagał interes polityczny, Książę był osobą moralnie dobrą i religijną, innym zaś razem - złą i areligijną. Nigdy jednak religia nie mogła dominować nad polityką. Ostatecznie Machiavelli uczynił z religii element gry politycznej. Zarysowaną formę zinstrumentalizowania religii możemy nazwać za niemieckim filozofem religii Bernhardem Welte polityczną ideologizacją religii. ${ }^{32}$

Dochodzi do niej wówczas, gdy religia traci swoją istotę, zachowując przy tym jedynie formę religii. ${ }^{33}$ Wydaje się, że zawsze jest to najpierw proces powodowany przez samych wyznawców religii. Welte zwrócił uwagę na to, że źródłowo proces ten rozpoczął się od koncentrowania się wyznawców religii na tym, co pozostawało w gestii ich władzy. ${ }^{34}$ Słuszność tego twierdzenia potwierdza opisana wyżej religijna działalność Savonaroli. Wyznawcy religii rozrządzają formą religijną, a więc powierzchniowym umotywowaniem religijnych działań wyznawców. Poprzez formę religijną wyznawcy religii mogą dążyć do osiągnięcia immanentnej władzy, mogą uczynić z formy religijnej instrument umożliwiający bądź pomagający realizować ich własne dążenia i cele. W tym sensie forma religijna może się stać instrumentem rozszerzania zakresu władzy. A wraz z przejęciem przez politykę dominacji nad religią ta ostatnia staje się instrumentem do rozszerzania władzy w państwie. Władza się degeneruje, bywa nierzadko zła, stąd sprawujący władzę chcą ją ubrać w czcigodne religijne szaty, aby ona sama jawiła się jako czcigodna. ${ }^{35} \mathrm{~W}$ nowożytne pojęcie polityki wpisany jest więc proces przekształcania religii w ideologię władzy.

Zarysowany mechanizm przekształcania religii w ideologię władzy potwierdza funkcjonowanie państw, w których religią dominującą jest islam. Chodzi tu o niektóre państwa w obszarze BMŚ, w których wykształciły się organizacje terrorystyczne, chcące zastąpić istniejący w tych państwach porządek państwowy i społeczny opartym na szariacie ustrojem islamistycznym. Do tych organizacji należą: Algierska Grupa Zbrojna (GIA) i jej odgałęzienie, powstała w 1997 r. Salifacka Grupa Misji i Walki (GSPC), libański szyicki Hezbollah, palestyński sun-

\footnotetext{
${ }^{31}$ Por. ibidem, s. 44-45.

${ }^{32}$ Por. B. Welte, Ideologie und Religion, ..., s. 99-103.

${ }^{33}$ Por. ibidem, Filozofia religii,..., s. 241-242.

${ }^{34}$ Por. ibidem, s. 245.

${ }^{35}$ Por. ibidem, s. 246.
} 
nicki Hamas oraz tureckie Państwo Kalifatu. ${ }^{36}$ We Francji największą aktywność wykazuje Algierska Grupa Zbrojna (GIA), która jest odpowiedzialna za zamachy w metrze, kawiarniach, domach handlowych i szkołach. W roku 2005 francuskie służby specjalne dokonały wielu aresztowań terrorystów, w okręgu paryskim i normandzkim, z Salafickiej Grupy na rzecz Wiary i Walki, udaremniając wiele przygotowywanych przez tę organizację zamachów. ${ }^{37} \mathrm{~W}$ każdej z tych organizacji terrorystycznych religia ma postać zideologizowaną, to znaczy jest motywatorem do walki zbrojnej o osiągnięcie założonych politycznych celów.

\section{IDEOLOGIZACJA RELIGII WE WSPÓŁCZESNYM POJĘCIU POLITYKI}

We współczesnych słownikach odnajdujemy wiele znaczeń terminu polity$k a{ }^{38}$ Dowiadujemy się z nich między innymi, że polityka jest wiedzą (nauką), innym razem, że jest ona sztuką bądź że jest sposobem rządzenia państwem czy też organizowaniem w państwie władzy. Znajdujemy tam również określenia bardziej opisowe, upatrujące w polityce całokształt podejmowanych działań publicznych w celu uzyskania partycypacji we władzy oraz całokształt działań osób partycypujących we władzy związanych z organizowaniem życia publicznego. ${ }^{39}$ Wielość znaczeń terminu polityka nie ułatwia wyrobienia sobie właściwego na nią poglądu. Polityka mieni się więc różnymi barwami i ich odcieniami, stąd czymś ryzykownym byłoby silenie się w tak krótkim opracowaniu na odtworzenie jej współczesnego portretu własnego. ${ }^{40} \mathrm{~W}$ niniejszym studium interesuje nas takie pojęcie polityki, w którego definicję niejako wpisana jest już realizacja programu zawartego w nowożytnym pojęciu polityki, współczesne bowiem pojęcie polityki nie odbiega istotnie od jej pojęcia ukształtowanego w nowożytności.

W myśl tego pojęcia do głównych zadań polityki należy wypracowywanie narzędzi umożliwiających obejmowanie władzy i sztukę jej utrzymywania. Współczesne pojęcie polityki jest podbudowywane bądź ideologią marksizmu komunistycznego, bądź ideologicznego liberalizmu, bądź wreszcie nurtem myślowym nawiązującym do wspomnianych ideologii zwanych postmodernizmem. Ze względu na rozległość zagadnienia ograniczymy się do ukazania tego, w jaki

${ }^{36}$ Por. B. Hołyst, op. cit., s. 525.

${ }^{37}$ Por. ibidem, s. 531. t. 6, Warszawa 2004, s. 537-538.

${ }^{38}$ Por. P. Kaczorowski, Polityka, [w:] Nowa encyklopedia powszechna, t. 6, red. B. Kaczorowski, Warszawa 200, s. 537-38.

39 „Polityka oznacza dążenie do udziału we władzy lub do wywierania wpływu na podział władzy czy to między państwami, czy to w obrębie państwa między grupami ludzi, jakie ono obejmuje". M. Weber, Polityka jako zawód i powołanie, tłum. A. Kopacki, P. Dybel, Społeczny Instytut Wydawniczy „Znak”, Kraków 1998, s. 55.

${ }^{40}$ Więcej na temat różnych znaczeń terminu polityka, zob. F. Ryszka, O pojęciu polityki, Warszawa 1992. 
sposób współczesne pojęcie polityki ukształtowane na bazie ideologii marksistowskiej i myśli postmodernistycznej inspiruje proces ideologizowania religii.

Współcześnie pojęcie ideologii ewoluowało od pejoratywnego jej znaczenia do uznania ideologii za konstytutywny element polityki. W marksizmie jak w pigułce widać ewolucję tego pojęcia. Marks, podobnie jak Hegel, utrzymywał, że ideologia jest fałszywą świadomością. Odrzucił przy tym przekonanie Hegla dotyczące roli człowieka w historii. Hegel utrzymywał, że ludzie, będąc nieświadomymi instrumentami historii, odgrywają role przypisane im przez siły, których nie rozumieją ${ }^{41}$ Według Marksa przyjęcie tego poglądu wzmacnia ideologię, poprzez którą władza oszukuje swych podwładnych, aby utrzymać polityczne status quo. Jeśli jednostki odgrywałyby role, których nie byłyby świadome, wówczas nie dostrzegałyby żadnego sensu jakichkolwiek reform, politycznych zmian. ${ }^{42}$ Marks jednak w używaniu terminu ideologia nie był konsekwentny. Niektóre konteksty, w jakich używał tego terminu, wskazują, że kojarzył on ideologię z prawdą. Efektem nadawania terminowi ideologia przeciwstawnych znaczeń i zabarwień emocjonalnych było to, że już dwudziestowieczni marksiści nie wiązali z tym terminem pejoratywnych odczuć, a nawet sami mówili o marksizmie jako ideologii. ${ }^{43}$ Lenin był przekonany, że ideologią posługuje się każda klasa społeczna, nie tylko klasa dominująca. ${ }^{44}$ Ideologia nabiera więc politycznego i aksjologicznego znaczenia w zależności od tego, czyim interesom służy. ${ }^{45}$ Marksizm ewoluował od autoidentyfikacji filozoficznej do autoidentyfikacji ideologicznej, stając się wręcz paradygmatem ideologii.

Ideologia marksistowska wpisana w politykę programowo miała służyć interesom klasy proletariackiej. Była krytyczna wobec czynników, które nie służyły tym interesom w sposób określony przez marksizm. Wśród wspomnianych czynników na ostrzu krytyki znalazła się religia. W marksistowskiej krytyce religii chodziło o to, aby ideologia mogła zawłaszczyć rolę, którą spełniała dotąd w życiu społecznym religia. ${ }^{46}$ Polityczne zideologizowanie religii w marksizmie przybrało postać jeszcze bardziej radykalną aniżeli w nowożytnym pojęciu polityki. Marksizm już nie upolityczniał religii, lecz religię wyręczył, czyniąc siebie religia. Ideologia marksistowska aspirowała do bycia soteriologią. Była bardzo oporna na krytykę, bo uniemożliwiała dostęp do źródeł prawdy poprzez uderzenie w metafizykę i religię. Tymczasem „bez zdrowej metafizyki i religii Objawionej

${ }^{41}$ Por. Ideologia, [w:] Britanica - edycja polska, ..., s. 46.

${ }^{42}$ Por. ibidem; P. Jaroszyński, Nauka w kulturze, Polskie Wydaw. Encyklopedyczne, Radom 2002, s. 282.

${ }^{43}$ „W niektórych krajach bloku radzieckiego ustanowiono instytucje ideologiczne, a o filozofach partyjnych mówiono jako o partyjnych ideologach". Ideologia, [w:] Britanica - edycja polska, ..., s. 46.

${ }^{44}$ Por. P. Jaroszyński, op. cit., s. 282.

${ }^{45}$ Por. ibidem, przyp. 464.

${ }^{46}$ Por. ibidem, s. 284. 
wręcz niemożliwe jest ukazanie fałszywych fundamentów, na których opiera się ideologia, zarówno co do samych założeń, jak i metod poznania i działania". ${ }^{47}$

Marksizm stał się inspiracją i bazą dla szkoły frankfurckiej..$^{48}$ Podjęto w niej badania nad stanem współczesnego społeczeństwa i nad politycznymi sposobami jego naprawy. Zasadnicze pytanie, jakie stawiali frankfurtczycy, dotyczyło przydatności materializmu historycznego w realizacji tych zadań. Sformułowano teorię krytykującą stechnokratyzowane społeczeństwo. Głównymi reprezentantami tej szkoły byli: M. Horkheimer, Th. W. Adorno, H. Marcuse, J. Habermas. Opracowali oni szczegółowo doktrynę tej szkoły. Horkheimer stworzył krytyczną teorię społeczeństwa i człowieka, gdyż, jak utrzymywał, współczesne społeczeństwo i kultura masowa zniewalają jednostkę. Programem jego teorii jest wolność i indywidualność człowieka, $\mathrm{i}$ to one winny być głównym celem do zrealizowania przez politykę. Adorno metodą negatywnej dialektyki bronił jednostki, jej rozumu i myślenia. Utrzymywał, że jedynie poprzez negację i poszukiwanie odmienności można poznawać to, co w rzeczy charakterystyczne i niepowtarzalne. Metodę negatywnej dialektyki wykorzystał Marcuse we własnej dialektycznej teorii społeczeństwa podważającej zastany w społeczeństwie porządek. Politycznym programem jego doktryny jest oswobodzenie człowieka z konformistycznego myślenia i działania. Człowiek jest zniewolony, jeśli myśli tak samo jak inni, potrzebuje tego, co inni, który dostosowuje się do wszystkiego.

Głoszony przez teorię krytyczną program zmiany życia społecznego wynikał z przyjmowanego twierdzenia o doczesności człowieka. Teoria krytyczna odrzuciła dualizm świata materialnego i duchowego, stając się teorią materialistyczną. ${ }^{49}$ Nie znaczy to jednak, że wyeliminowała religię z kultury. Przeciwnie, oskarżyła pozytywistyczny scjentyzm za przyczynienie się do upadku człowieczeństwa, eliminując z kultury myślenie religijno-metafizyczne i wiążącą się z nim potrzebę wartości. ${ }^{50}$ Zaznaczmy przy tym, że teoria krytyczna zrelatywizowała kategorie właściwe poszczególnym dziedzinom kultury. W odniesieniu do religii zrobiła to poprzez promocję pluralizmu religijnego i wolności religijnej. Urzeczywistnienie idei pluralizmu religijnego miało doprowadzić do rozchwiania przekonań religijnych aż do zakwestionowania istnienia religijnej prawdy. Polityczny program realizowany przez postmodernizm polega na przeciwstawianiu się prawdzie i nieustannej pogoni za zwiększaniem władzy. ${ }^{51}$

\section{${ }^{47}$ Ibidem.}

${ }^{48}$ Zob. M. J. Inwood, Frankfurt School, [w:] The Oxford Companion to Philosophy, red. T. Honderich, Oxford Univerity Press, Oxford, New York 1995, s. 290.

${ }^{49}$ Por. H. Jakuszko, Frankfurcka szkoła, [w:] Powszechna encyklopedia filozofii, red. A. Maryniarczyk i in., t. 3, Polskie Towarzystwo Tomasza z Akwinu, Lublin 2002, s. 613.

${ }^{50}$ Por. ibidem, s. 614.

${ }^{51}$ Por. Th. A. Milhaud, Problematyczna polityka postmodernistycznego pluralizmu, [w:] Polityka a religia, red. P. Jaroszyński i inni, tłum. A. Lekka-Kowalik, Lublin 2007, s. 49. Program ten został nazwany polityką absolutnej odmienności, por. ibidem, s. 51. 
Wraz z postmodernizmem polityczna ideologizacja religii powróciła w nowej formie. Polega ona na przypisywaniu religii wyłącznie funkcji społecznej. Daniel Dennett postrzega religię już tylko jako system społeczny. ${ }^{52}$ Podobnie Zygmunt Bauman sugeruje, aby nie wdawać się w jakiekolwiek próby definiowania religii, gdyż zabieg ten nie ma większego praktycznego znaczenia. Zastanawiać się nad tym, czym religia jest, albo - co ona robi, nie ma sensu. ${ }^{53}$ Zdaniem Baumana należy badać mechanizmy życia społecznego, które doprowadziły do wytworzenia religii oraz badać samą religię jako mechanizm życia społecznego. ${ }^{54}$ Jeśli więc nie ma sensu refleksja nad soteriologią religii, to jej obecność w kulturze może być usensowniona jedynie polityczną rolą. Jednakże jest to zawsze rola, jaką wyznacza religii aktualna polityka. Polityka jest więc nadrzędna w stosunku do religii. Ostatecznie religia w teorii krytycznej to instrument polityki, której istotną rolą jest dochodzenie do władzy i jej utrzymanie. Jednakże ceną, jaką się za to płaci, jest utrata wewnętrznego bezpieczeństwa państwa w obszarze kulturowym.

\section{WNIOSKI KOŃCOWE}

Religii w warstwie teoretycznej nie mogą wyręczyć ani nauki przyrodnicze, ani filozofia. Odpowiedzi dotyczące ostatecznego sensu życia człowieka należą do religii. Podobnie w warstwie praktycznej religii nie może zastąpić ideologia ani polityka. Religia dostarcza jednostce pomocy duchowych w dochodzeniu do zbawienia, i to jest jej właściwe zadanie wobec człowieka - jednostki. Do politycznej ideologizacji religii dochodzi wówczas, gdy religii wyznacza się urzeczywistnianie celów grupowych, które istotnie spełnia polityka. Efektem niniejszego studium jest rekonstrukcja mechanizmu ideologizowania religii w nowożytnym i współczesnym pojęciu polityki oraz ukazanie skutków tego procesu dla bezpieczeństwa państw w BMŚ. Proces ideologizowania religii najczęściej zapoczątkowują sami wyznawcy religii, identyfikując ją z formą religijną. Religia jest następnie przyporządkowywana i podporządkowywana polityce, by w końcu postrzegać ją już tylko jako ideologiczny system o znaczeniu społecznym. W tym ostatnim kształcie religia jest już całkowicie wydziedziczona z przysługującej jej właściwej soteriologicznej roli wobec człowieka - jednostki. Na każdym etapie proces ideologizowania religii, bez względu na podmiot, który tego dokonuje, systematycznie osłabia poziom wewnętrznego bezpieczeństwa państw, w których do takiej politycznej ideologizacji religii dochodzi. Spektakularnym skutkiem politycznej ideologizacji religii jest powstawanie organizacji terrorystycznych oraz

${ }^{52}$ Por. D. C. Dennett, Odczarowanie, religia jako zjawisko naturalne, thum. B. Stanosz, Państwowy Instytut Wydawniczy, Warszawa 2008, s. 31.

${ }^{53}$ Parafrazuję myśl Baumana za J. Beckford, Teoria społeczna a religia, thum. M. Kunz, T. Kunz, Zakład Wydawniczy „Nomos”, Kraków 2006, s. 41.

${ }^{54}$ Zob. Z. Bauman, Ponowoczesność jako źródło cierpień, Wydawnictwo Sic!, Warszawa 2000, s. $277 \mathrm{nn}$. 


\title{
ich zbrodnicza działalność, której ofiarami są najczęściej niewinni i nieświadomi tego procesu ludzie.
}

\section{THE IDEOLOGIZATION OF RELIGION AS A THREAT TO MEDITERRANEAN COUNTRIES}

\begin{abstract}
This article aims to reconstruct the mechanisms of politicization and ideologization of religion in modern and contemporary understandings of politics and to present the threats to internal security that it could cause. Security risks resulting from the ideologization of religion are illustrated by contemporary Islamism, which inspires actions by terrorist organizations in some countries of the Mediterranean basin. In a theoretical layer of the process this ideologization manifests itself in the fact that religious assertions about transcendentally significant ideas are internalized as immanent. In terms of practice, the ideologization means the domination of the group's objectives over individual objectives of religion resulting from its very nature. The article shows the modern source of the ideologization of religion and its modern and contemporary transformational mechanisms into an ideology of power. This study establishes a causal relationship between an ideologized form of religion and security threats.
\end{abstract}

Key words: security, ideology, ideologization of religion, politics, terrorism 